\title{
Prospective Analysis of the Chronology of Smell and Taste Dysfunction in COVID-19 Positive ENT Doctors
}

\author{
Prem Sagar $^{1}\left(\mathbb{C} \cdot\right.$ Rajeev Kumar $^{1} \cdot$ Raeza Fatima $^{1} \cdot$ Sumanth Bollu $^{1} \cdot$ \\ Namrita Mehmi ${ }^{1,2} \cdot$ A. S. Subagar ${ }^{1} \cdot$ Alok Thakar $^{1}$
}

Received: 3 March 2021 / Accepted: 12 April 2021/Published online: 23 April 2021

(C) Association of Otolaryngologists of India 2021

\begin{abstract}
Olfactory and gustatory dysfunction has been reported as an early presentation in COVID-19. We intent to analyze the chronological outline of these chemosensory disturbances in term of onset, progression and resolution in ENT doctors with COVID-19. In six symptomatic otolaryngologists who tested positive for SARS-CoV-2, detailed symptomatology of olfactory and gustatory dysfunction was collected prospectively on regular basis till a period of at least three months. Due to their awareness, sensitivity and reliability, even mild and transient relevant symptomatology could be recorded accurately. Olfactory and gustatory dysfunction was universally present in all the six otolaryngologists. The onset of the symptoms was in first week and resolved completely within 4 weeks in four of them. In two doctors the recovery of olfactory dysfunction to near normal level was delayed and prolonged over 2 and 3 months. The pattern of involvement of basic tastes like sweet, salt, sour and bitter as well as food temperature and texture etc. pointed towards involvement of the gustatory mucosa with non-uniform involvement of the papilla and taste receptors. One of the doctors also experienced reappearance of parosmia and phantosmia in the 3rd month following complete disease resolution. Due to their expertise in the field of Otolaryngology, the recruited doctors represented the precise pattern of progression and resolution of olfactory and gustatory
\end{abstract}

Prem Sagar

sagardrprem@gmail.com

1 Department of Otorhinolaryngology and Head Neck Surgery, All India Institute of Medical Sciences, New Delhi 110029, India

2 Present Address: Park Hospital, Sohna road, Sector 47, Gurugram, India dysfunction in COVID-19. Larger studies are needed to validate our reported universal presence of these symptoms with complete recovery rate following disease resolution.

Keywords Anosmia in COVID-19 · Hyposmia ·

Phantosmia $\cdot$ Dysgeusia $\cdot$ Hypogeusia $\cdot$ Otolaryngologists

\section{Introduction}

The coronavirus disease 2019 (COVID-19) is a viral pandemic spreading at a rapid pace across the globe. Common presentation of COVID-19 includes fever, cough, myalgia, sore throat, rhinorrhea, headache, shortness of breath and diarrhea [1,2]. Anosmia and dysgeusia has been reported by many otolaryngologists across the world as early symptoms of COVID-19. The incidence of olfactory and gustatory dysfunction in COVID-19 has been reported as 19-88\% [3-6]. However, the chronological outline of these chemosensory disturbances in COVID-19 is limited due to retrospective nature of studies and unavailability of longterm follow-up. In this prospective study on six COVID-19 positive symptomatic ENT doctors, we have analyzed the pattern of evolution and resolution of olfactory and gustatory changes till a minimum of three months.

\section{Materials and Methods}

This case series is based on the analysis of prospectively recorded data related to smell and taste disturbances experienced by 6 symptomatic COVID-19 positive otorhinolaryngologists. With due permission from institutional ethical committee, we documented the symptomatology of these doctors who consented to provide detailed 
and accurate relevant data for analysis and publication. The 6 doctors experienced symptoms while being actively involved in ENT out-patient department and operation theatre while following the recommended protocol on the usage of personal protective equipment as per the institute. Following their positive result on reverse transcriptase polymerase chain reaction (RT-PCR) testing for SARS-CoV-2, five of them were hospitalized in isolation wards and one doctor opted for home isolation. During their disease course, they were contacted telephonically on daily basis for their general symptoms as well as symptoms related to smell and taste. Being otorhinolaryngologists, they could notice and report precisely about their smell and taste dysfunction with regard to onset, progression and recovery on day-to day basis for at least three months.

\section{Results}

The demographic and basic disease related details are listed in Table 1. All infected doctors experienced mild disease severity as per the WHO Interim Guidelines for Clinical Management of COVID-19. All the doctors received symptomatic treatment based on the evidence available at that point of time as well as local health authority guidelines. The first presenting feature in all the doctors were fever and myalgia. The incidence of other symptoms were as follows: cough -3 patients, diarrhea-3, headache-2, sore throat -3 , nasal congestion -3 , and rhinorrhoea in 1 patient. All of them experienced asthenia for a variable period of time (7-45 days) starting from first day of symptom onset to 7 days after symptom onset.

Half of the doctors had smell as well as taste disturbances with onset within 3 days of being symptomatic and rest three doctors reported onset of anosmia within the first week. The onset, progress and resolution of smell dysfunction of all the doctors is briefed in Table 2. Four of the doctors reported anosmia and two experienced hyposmia. All the 6 doctors had taste disturbances in the form of hypogeusia in five and dysgeusia in three of them. The onset of these symptoms were within first 6 days in all of them. Complete loss of taste was reported by one doctor who experienced significant hyposmia. The rest of the doctors, though had anosmia, experienced hypogeusia or dysgeusia. One doctor experienced dysguesia (persistent bitterness in the mouth) only on the second day. The recovery pattern of each basic taste function along with sensations mediated by the trigeminal nerve is mentioned in Table 3.

In the first doctor, 11 weeks after the symptom onset and following complete symptomatic relief, complaints of phantosmia (strong odour of onion) and significant parosmia to all food items and day-to-days items like skin creams, body odour etc.appeared. These symptoms quickly progressed and was reported as unbearable making all the food items unpalatable by the doctor which lasted for 10 days. The symptoms gradually improved over next 6 days making the doctor symptom free on day 16. All the basic tastes were intact and the doctor did not experience any other symptoms. During this phase, repeat RT-PCR for COVID-19 was negative and the antibodies against the virus was more than 10 Index which was done during 7th week ( 4 weeks before the symptom recurrence).

\section{Discussion}

The literature on COVID-19 reports of smell and taste disturbances in a widely variable proportion of patients, ranging from 15.7 to $88 \%[5,7]$. This small case series limited to six Otolaryngology doctors with COVID19 infection finds smell and taste disturbances to be universally noted by all. Otolaryngology doctors are likely to be precisely aware of symptoms related to smell and taste, and hence the sensitivity and accuracy of these symptoms are therefore best captured in this case group. This case group also provided all the insight into the patients'

Table 1 Demographic and basic disease related details of all cases

\begin{tabular}{|c|c|c|c|c|c|c|}
\hline $\begin{array}{l}\text { Demographic and overall } \\
\text { disease related details }\end{array}$ & Case 1 & Case 2 & Case 3 & Case 4 & Case 5 & Case 6 \\
\hline Age/sex & 29/female & $31 /$ male & 32/female & 28/male & $27 /$ male & 27/female \\
\hline Co-morbidity & None & None & None & None & None & None \\
\hline Symptom severity & Mild & Mild & Mild & Mild & Mild & Mild \\
\hline $\begin{array}{l}\text { Type of exposure (high risk/ } \\
\text { low risk/intermediate) }\end{array}$ & Unknown & Unknown & Unknown & Unknown & Unknown & Unknown \\
\hline Initial presentation & $\begin{array}{c}\text { Fever, sore } \\
\text { throat, } \\
\text { myalgia }\end{array}$ & $\begin{array}{l}\text { Fever, } \\
\text { diarrhea, } \\
\text { malaise }\end{array}$ & $\begin{array}{l}\text { Fever, } \\
\text { myalgia, } \\
\text { malaise }\end{array}$ & $\begin{array}{l}\text { Fever, malaise, } \\
\text { headache }\end{array}$ & $\begin{array}{l}\text { Fever, malaise, sore } \\
\text { throat, cough }\end{array}$ & $\begin{array}{l}\text { Fever, myalgia, } \\
\text { nasal congestion }\end{array}$ \\
\hline
\end{tabular}


Table 2 The chronology and character of olfactory disturbances in all cases

\begin{tabular}{|c|c|c|c|c|c|c|}
\hline $\begin{array}{l}\text { Smell related symptoms/signs (in } \\
\text { days starting from the day of onset of } \\
\text { first symptom(s) as day 1) }\end{array}$ & Case 1 & Case 2 & Case 3 & Case 4 & Case 5 & Case 6 \\
\hline Day of onset and type & 3, hyposmia & $\begin{array}{l}3 \text {, phantosmia (persistent smell of } \\
\text { vomitus) }\end{array}$ & 3, & 7, & 5, & 6, hyposmia \\
\hline $\begin{array}{l}\text { Days of maximal dysfunction and } \\
\text { type }\end{array}$ & $\begin{array}{l}4 \text { and } 5 \text {, } \\
\text { anosmia }\end{array}$ & $\begin{array}{l}\text { 4-11, significant hyposmia (some } \\
\text { smells like floor cleaners and } \\
\text { deodorant perceived minimally) }\end{array}$ & $\begin{array}{l}\text { 3-16, } \\
\text { anosmia }\end{array}$ & $\begin{array}{l}7-12 \\
\quad \text { anosmia }\end{array}$ & $\begin{array}{l}5-25, \\
\quad \text { anosmia }\end{array}$ & $\begin{array}{l}\text { 6-8, } \\
\text { hyposmia }\end{array}$ \\
\hline Improvement course in days & 6 till 26 & 12 till 25 & 17 till 90 & 13 till 20 & $26-60$ & 9,10 \\
\hline Duration (onset to maximal recovery) & 24 days & 23 days & 88 days & 14 days & 55 days & 5 days \\
\hline Complete recovery & Yes & Yes & Almost & Yes & Almost & Yes \\
\hline $\begin{array}{l}\text { Associated nasal symptoms/signs and } \\
\text { duration }\end{array}$ & $\begin{array}{l}\text { Rhinorrhea: } \\
\text { 2-4 Nasal } \\
\text { congestion: } \\
\text { 5-13 }\end{array}$ & Nasal congestion: $5-7$ & None & None & None & $\begin{array}{l}\text { Nasal } \\
\text { stuffiness, } \\
1-6\end{array}$ \\
\hline
\end{tabular}

prospective on olfactory and gustatory dysfunction relevant to Otolaryngologists.

Smell and taste disturbance are much less likely in other illnesses presenting with upper respiratory catarrh or pharyngitis and fever. The commonly associated viruses with such dysfunction are rhinovirus, parainfluenza virus, corona virus and Epstein-Barr virus [8]. However, approximately $1 \%$ of patients suffer from permanent anosmia which has been corelated with reduced number of olfactory receptors, decreased volume of olfactory bulb and hypometabolism in the areas of central olfactory projections [9-14]. A recovery rate over many years has been quoted as one third to two third of all patients with viral upper respiratory infections $[15,16]$.

Among COVID-19 positive patients, these chemosensory dysfunction appear within initial three days in $85 \%$ of cases [17]. The incidence of phantosmia and parosmia has been reported as $12.65 \%$ and $32.4 \%$ respectively [5]. The gustatory dysfunction in the form of hypogeusia and ageusia has been found in $78.9 \%$ and $21.1 \%$ of patients, respectively [5]. Taste disturbances co-existing with smell disturbances have been reported in $55 \%$ of cases and in $1.5 \%$ of cases without any smell related symptoms [17]. The short term recovery rate for smell disturbances has been quoted as $44 \%$ and the median recovery time for both the chemosensory dysfunction has been noted as 7 days, whereas most of the patients recover within 3 weeks $[5,15]$.

As most of the reported studies are retrospective, the symptoms of trivial smell and taste related disturbances may suffer from unawareness, underestimation and recall bias, which was present in $7.6 \%$ of patients as reported by Leichien et al. [5]. This limitation has been addressed in our small prospective series where even minimal and transient symptoms were reported. Hence, a higher incidence of smell and taste disturbances in COVID-19 positive cases may be expected as compared to already reported in literature. As all the doctors were followed up till complete recovery and as maximum as three months after first symptoms, we noticed $100 \%$ recovery rate in both smell and taste disturbances in this series as compared to the reported $15 \%$ and $59.7 \%$ incidences of no recovery rate in taste and smell disturbances respectively [17].

The onset of taste dysfunctions in our series, was within first three days in three of the doctors and maximum dysfunction lasted just for a day. Recovery trend started early and all of them reported complete recovery by the end of 4-5th week. One doctor who presented with gastrointestinal symptoms, experienced slightly delayed onset ageusia which lasted for a week, but recovered completely by 4th week. Recovery of taste function was reported as complete following appreciation of aroma of food items and not following complete return of just the basic taste sensations. Recovery of food flavors roughly corresponded with recovery of smell function by $75-80 \%$ as reported by the otolaryngologists in this case group. We noticed that the more is the total duration of maximal chemosensory dysfunction, the longer is the recovery time. Also, though the onset of both smell and taste dysfunction had a similar temporal pattern, there was no specific association between the recovery trend and duration.

The different basic taste dysfunction combinations could not be explained by affected specific types of papilla over the tongue mucosa responsible for sensing specific tastes. The third doctor had affected salty and bitter taste but not sweet whereas both salt and sweet taste are perceived by fungiform papillae. Similarly, involvement of different sensory nerves carrying the taste sensations from different 
Table 3 The character and chronology of gustatory dysfunction in all cases

\begin{tabular}{|c|c|c|c|c|c|c|}
\hline $\begin{array}{l}\text { Symptoms/signs (Day } 1 \text { is } \\
\text { the day of onset of first } \\
\text { symptom related to } \\
\text { COVID-19) }\end{array}$ & Case 1 & Case 2 & Case 3 & Case 4 & Case 5 & Case 6 \\
\hline $\begin{array}{l}\text { Day of onset of gustatory } \\
\text { dysfunction, type }\end{array}$ & 3 , hypogeusia & $\begin{array}{l}\text { 3-dysgeusia, } \\
\text { hypogeusia }\end{array}$ & $\begin{array}{l}\text { 3-dysgeusia, } \\
\text { hypogeusia }\end{array}$ & $\begin{array}{l}\text { 2-dysgeusia } \\
\text { (persistent } \\
\text { bitter } \\
\text { taste) }\end{array}$ & $\begin{array}{l}\text { 5-(hypogeusia } \\
\text { to bitter } \\
\text { taste) }\end{array}$ & $\begin{array}{l}\text { 6, hypogeusia to } \\
\text { bitter, sweet, } \\
\text { sour }\end{array}$ \\
\hline $\begin{array}{l}\text { Day of maximal } \\
\text { dysfunction, type }\end{array}$ & $\begin{array}{l}\text { 3, significant } \\
\text { hypogeusia }\end{array}$ & $6-12$, ageusia & $\begin{array}{l}\text { 3-hypogeusia and } \\
\text { dysgeusia }\end{array}$ & 2 & $\begin{array}{l}5,6 \\
\text { hypogeusia }\end{array}$ & 6,7 hypogeusia \\
\hline $\begin{array}{l}\text { Improvement pattern } \\
\text { noticed (on day) }\end{array}$ & 4 till 26 & $13-30$ & $\begin{array}{l}4 \text { till } 17 \text { for } \\
\text { hypogeusia4 till } \\
\text { 35-dysgeusia }\end{array}$ & 2 & 7 & $8-10$ \\
\hline Complete recovery & Yes & Yes & Yes & Yes & Yes & Yes \\
\hline $\begin{array}{l}\text { Total duration of } \\
\text { dysfunction (in days) }\end{array}$ & 24 & 28 & 35 & 1 & 2 & 5 \\
\hline $\begin{array}{l}\text { Other oral symptoms and } \\
\text { signs }\end{array}$ & Sore throat: $1-4$ & $\begin{array}{l}\text { Median glossitis, } \\
\text { Burning sensation } \\
\text { on food intake: } \\
15-19\end{array}$ & Sore throat: $20-25$ & None & $\begin{array}{l}\text { Sore throat: } \\
\quad 1-4\end{array}$ & None \\
\hline $\begin{array}{l}\text { Loss and recovery pattern } \\
\text { for salt taste }\end{array}$ & $\begin{array}{l}\text { Complete loss- } \\
\text { day } 3, \\
\text { recovery } \\
\text { started on day } \\
8, \text { recovered } \\
\text { on day } 9\end{array}$ & $\begin{array}{l}\text { Hypo-day } 4,5, \\
\text { complete loss: } 6-12, \\
\text { recovery started on } \\
\text { day } 15 \text {, complete } \\
\text { recovery day } 20\end{array}$ & $\begin{array}{l}\text { Hypo-day } 3, \\
\text { complete } \\
\text { recovery-17 }\end{array}$ & - & - & - \\
\hline $\begin{array}{l}\text { Loss and recovery pattern } \\
\text { of sweet }\end{array}$ & $\begin{array}{l}\text { Complete loss- } \\
\text { day } 3, \\
\text { recovery } \\
\text { started on day } \\
8, \text { recovered } \\
\text { on day } 9\end{array}$ & $\begin{array}{l}\text { Hypo-day } 5 \text {, } \\
\text { complete loss: } 6-12, \\
\text { recovery started on } \\
\text { day } 15 \text {, complete } \\
\text { recovery day } 20\end{array}$ & No loss & - & - & $\begin{array}{l}\text { Hypo, } 6,7, \\
\text { recovery } \\
\text { started on } 8 \\
\text { and complete } \\
\text { recovery by } \\
\text { 10th day }\end{array}$ \\
\hline $\begin{array}{l}\text { Loss and recovery pattern } \\
\text { of sour }\end{array}$ & $\begin{array}{l}\text { Reduced-day } 3 \text {, } \\
\text { recovery } \\
\text { started on day } \\
8 \text {, complete } \\
\text { recovery day } 9\end{array}$ & $\begin{array}{l}\text { Complete loss-4-18 } \\
\text { Recovery started on } \\
\text { day } 19, \text { complete } \\
\text { recovery on day } 20\end{array}$ & No loss & - & - & $\begin{array}{l}\text { Hypo, } 6,7, \\
\text { recovery } \\
\text { started on } 8 \\
\text { and complete } \\
\text { recovery by } \\
\text { 10th day }\end{array}$ \\
\hline $\begin{array}{l}\text { Loss and recovery pattern } \\
\text { for bitter }\end{array}$ & $\begin{array}{l}\text { Reduced-day } 3 \text {, } \\
\text { recovery } \\
\text { started on day } \\
8, \text { complete } \\
\text { recovery day } 9\end{array}$ & $\begin{array}{l}\text { Complete loss:4-18 } \\
\text { Recovery started on } \\
\text { day } 19, \text { complete } \\
\text { recovery on day } 20\end{array}$ & $\begin{array}{l}\text { Hypo-day } 3, \\
\text { recovery-17 }\end{array}$ & - & Нyро, day 5,6 & $\begin{array}{l}\text { Hypo, } 6,7, \\
\text { recovery } \\
\text { started on } 8 \\
\text { and complete } \\
\text { recovery by } \\
\text { 10th day }\end{array}$ \\
\hline $\begin{array}{l}\text { Sense of food } \\
\text { temperature/texture/pain }\end{array}$ & $\begin{array}{l}\text { hotness of chilies } \\
\text { and raw } \\
\text { onions not } \\
\text { perceived }\end{array}$ & $\begin{array}{l}\text { Persistent burning } \\
\text { sensation }\end{array}$ & $\begin{array}{l}\text { Loss of } \\
\text { cooling sensation } \\
\text { after using } \\
\text { menthol-based } \\
\text { gargle }\end{array}$ & Intact & Intact & Intact \\
\hline
\end{tabular}

parts of the tongue also could not explain the pattern of taste disturbances in our series. Type 1 gustatory receptors are associated salt and sweet taste, type 2 receptors with sour and type 3 with bitter taste sensation. Involvement of specific types of taste receptors also could not explain the dysfunction pattern. There was overlapping pattern of basic taste disturbances due to dysfunction of multiple types of receptors and the loss of salt and bitter taste with preserved sweet taste in the third doctor could not be explained by the receptor concept alone as suggested by many studies [18-20]. However, type 3 receptor dysfunction was universally present in the doctors who experienced hypo/ 
ageusia. We also noticed that the sense of temperature and hotness of chilies was lost in two of our doctors suggesting the disease involvement of the tongue mucosa which also perceive the temperature, pain and texture sense through the papillae and further carried by branches of trigeminal and glossopharyngeal nerve. After analyzing all the possible mechanisms of taste dysfunction based on the involvement of individual types of taste, dysfunction of the gustatory mucosa by virus with non-uniform dysfunction of different types of tastes and sensation from the tongue seems the most probable explanation. Also, virus infiltration of the oral mucosa may be associated with salivary transmission of the novel corona virus which may result in disease transmission through shared food items and cutlery when not disinfected properly.

In one of the doctors, the occurrence of phantosmia and parosmia 11 weeks after onset of COVID-19 and complete disease recovery may represent a delayed neurological sequelae though we could not undertake a neuroimaging study during this symptomatic recurrence. No such incidences have been reported till date regarding delayed onset smell or taste dysfunction after disease resolution. Reactivation of the viral activity in the involved nerves and central nervous system when the antibody level declines in the blood, may explain this type of symptoms as seen in cases of herpes virus induced Bell's palsy and Ramsay Hunt syndrome. However, this postulation need further research to be proved or disproved.

The limitations associated with this study are the small number of cases and lack of objective tests to quantify the olfactory and gustatory disturbances. The disease severity was mild in all the six doctors in this case series; hence we cannot generalize our results to all the cases of COVID-19.

\section{Conclusions}

Presence of olfactory and gustatory dysfunction in all the COVID-19 positive symptomatic otolaryngologists in our prospective case series, indicates towards the possible universal occurrence of chemosensory disturbances in COVID-19. We also noticed universal recovery of the chemosensory dysfunction in this case group. Based on the pattern of taste disturbances, involvement of gustatory mucosa may explain the non-uniform combination and severity of different taste as well as trigeminal nerve mediated sensations. Following complete disease resolution, we report the first instance of phantosmia and parosmia 11 weeks after disease onset with no other accompanying symptoms of COVID-19.
Author Contributions All the authors have contributed in the study and manuscript preparation as mentioned below. PS: Data collection, analysis, writing of the manuscript. RK: Data collection, writing of the manuscript. RFTS, SB, NM, SAS: Data collection, analysis. AT: Analysis, writing of the manuscript.

Funding None.

\section{Declarations}

Conflict of interest The author(s) declare that they have no conflict of interest.

Ethical Approval Approved by institute Ethical Committee, AIIMS, New Delhi, India for conduction of the study.

Informed Consent Written informed consent for publication was obtained from participants.

\section{References}

1. Young BE, Ong SWX, Kalimuddin S et al (2020) Epidemiologic features and clinical course of patients infected with SARS-CoV2 in Singapore. JAMA. https://doi.org/10.1001/jama.2020.3204

2. Wan S, Xiang Y, Fang W, Zheng Y et al (2020) Clinical features and treatment of COVID-19 patients in Northeast Chongqing. J Med Virol. https://doi.org/10.1002/jmv.25783

3. Vaira LA, Salzano G, Deiana G, de Riu G (2020) Ageusia and anosmia: common findings in COVID-19 patients. Laryngoscope. https://doi.org/10.1002/lary.28692

4. Giacomelli A, Pezzati L, Conti F et al (2020) Self-reported olfactory and taste disorders in SARS-CoV-2 patients: a crosssectional study. Clin Infect Dis. https://doi.org/10.1002/jmv.25794

5. Leichien JR, Chiesa-Estomba CM, de Siati DR et al (2020) Olfactory and gustatory dysfunction as a clinical presentation of mild-to-moderate forms of the coronavirus disease 9 COVID-19: a multicentre European study. Eur Arch Otorhinolaryngol. https://doi.org/10.1007/s00405-020-05965-1

6. Yan CH, Faraji F, Prajapati DP, Boone CE, DeConde AS (2020) Association of chemosensoty dysfunction and Covid-19 in patients presenting with influenza-like symptoms. Int Forum Allergy Rhinol. https://doi.org/10.1002/air.22579

7. Yonghyun L, Pokkee M, Seonggu L, Shin-Woo K (2020) Prevalence and duration of acute loss of smell or taste in COVID19 patients. J Korean Med Sci 35(18):e174

8. Suzuki M, Saito K, Min WP, Vladau C, Toida K, Itoh H, Murakami S (2007) Identification of viruses in patients with postviral olfactory dysfunction. Laryngoscope 117(2):272-277. https://doi.org/10.1097/01.mlg.0000249922.37381.1e

9. Hummel T, Landis BN, Huttenbrink KB (2011) Smell and taste disorders. GMS Curr Top Otorhinolaryngol Head Neck Surg. https://doi.org/10.3205/cto000077

10. Jafek BW, Hartman D, Eller PM, Johnson EW et al (1990) Postviral olfactory dysfunction. Am J Rhinol 4(3):91-100

11. Yamagishi M, Fujiwara M, Nakamura H (1994) Olfactory mucosal findings and clinical course in patients with olfactory disorders following upper respiratory viral infection. Rhinology 32:113

12. Yamagishi M, Hasegawa S, Nakano Y (1988) Examination and classification of human olfactory mucosa in patients with clinical olfactory disturbances. Arch Otorhinolaryngol 245:316 
13. Rombaux P, Mouraux A, Bertrand B et al (2006) Olfactory function and olfactory bulb volume in patients with postinfectious olfactory loss. Laryngoscope 116930:436-439

14. Kim YK, Hong SL, Yoon EJ et al (2012) Central presentation of postviral olfactory loss evaluated by positron emission tomography scan: a pilot study. Am J Rhinol Allergy 26(3):204-208

15 Hendriks APJ (1988) Olfactory dysfunction. Rhinology 26:229

16. Duncan HJ, Seiden AM (1995) Long term follow-up of olfactory loss to head trauma and upper respiratory tract infection. Arch Otolaryngol Head Neck Surg 121:1183

17. Abalo-Lojo JM, Pouso-Diz JM, Gonzalez F (2020) Taste and smell dysfunction in COVID-19 patients. Ann OtolRhinolLaryngol 129(10):1041-1042
18. Xu H, Zhong L, Deng J et al (2020) High expression of ACE2 receptor of 2019-nCoV on the epithelial cells of oral mucosa. Int J Oral Sci 12(1):8

19. Butowt R, Bilinska K (2020) SARS-CoV-2: olfaction, brain infection, and the urgent need for clinical samples allowing earlier virus detection. ACS ChemNeurosci 11(9):1200-1203

20. Yamagishi M, Fujiwara M, Nakamura H (1994) Olfactory mucosal findings and clinical course in patients with olfactory disorders following upper respiratory viral infection. Rhinology $32: 118-133$

Publisher's Note Springer Nature remains neutral with regard to jurisdictional claims in published maps and institutional affiliations. 